Apidologie, 1981, $12(3), 211-220$.

\title{
NATIVE LEAFCUTTER BEE SPECIES AND ASSOCIATED PARASITES IN COMMERCIAL HIVES IN SASKATCHEW AN, CANADA
}

\author{
G. H. RANK and D. W. GOERZEN \\ Dept. of Biology, University of Saskatchewan \\ Saskatoon, Saskatchewan, Canada, S7NOWO
}

\begin{abstract}
SUMMARY
Native leafcutter bee cells were sampled from four different commercial populations. The predominant native leafcutter bee species found in these commercial populations were Megachile relativa ( $99.7 \%$ ) and $M$. nivalis $(0.3 \%)$. Coelioxys funeraria and C. moesta, major parasites of $M$. relativa, were not observed to emerge from $M$. rotundata cells. Chalcids found in $M$. relativa cells were Dibrachys maculipennis, Melittobia chalybii and Pteromalus venustus. These could be removed from M. relativa by taking advantage of the earlier chalcid emergence. However, X-ray identification in the pupal stage was required for the removal of Coelioxys spp. since their emergence coincided with that of $M$. relativa. Limited success in domestication of $M$, relativa is reported.
\end{abstract}

\section{INTRODUCTION}

Three ground nesting species of the Megachile latimanus group, M. diligens, $M$. perihirta and M. latimanus were identified by Sladen (1918) as the major native pollinators of alfalfa (Medicago sativa) in Canada. A study by PECK and BoltoN (1946) near Prince Albert, Saskatchewan $\left(53^{\circ} 12^{\prime} 105^{\circ} 46^{\prime}\right)$ indicated that the main genera capable of tripping alfalfa flowers were Megachile and Bombus, while the genera Osmia, Coelioxys and Anthrophora were of limited value. They observed the following species of Megachile pollinating alfalfa: M. relativa, M. nivalis, M. gemula, M. frigida, M. melanophaea, M. inermis and M. latimanus. HoBBs and LiLly (1954) identified 14 species of Megachile in the alfalfa seed growing region of southern Alberta. Two ground nesting species, $M$. dentitarsus and $M$. perihirta, were the most important native pollinators of alfalfa while less important, in decreasing order, were M. brevis, M. melanophaea, M.frigida, and M.relativa. STEPHEN (1955) reported that in Manitoba $M$. frigida and $M$. latimanus consistently tripped greater than $90 \%$ of alfalfa flowers visited whereas the efficiency of $M$. relativa, $M$. melanophaea, 
M. inermis and M. brevis was lower and more varied. Although numerous studies in other locations have identified Megachile species in natural settings (GENTRY, 1874; Fye, 1965; Krombein, 1967; Medler and Koerber, 1958; Holm and SKou, 1972) there is no information to the authors' knowledge on native leafcutters attracted to commercial hives of $M$. rotundata. We report here on the biology of native leafcutter bee cells from four commercial Saskatchewan populations.

\section{MATERIALS AND METHOD}

Source of Cells

Cells of immigrant native leafcutter bees were identified by their distinctive morphology (Fig. 1). The cells are larger than those of $M$. rotundata and are smooth due to the firm packing of the

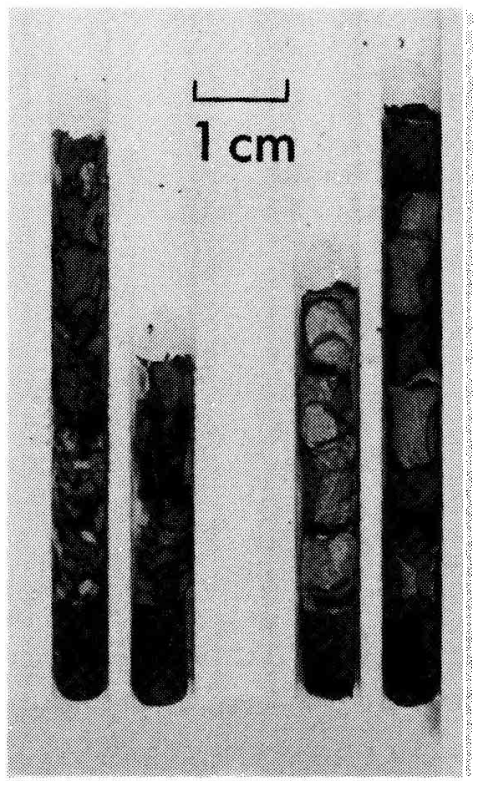

FIG. 1. - Photograph of Megachile cells showing M. relativa cells in the bottom of each of four tunnels. After the native leafcutters emerged, M. rotundata occupied the empty cells and continued to fill the tunnels.

leaf fragments. Native leafcutter cells were obtained from four commercial Saskatchewan populations

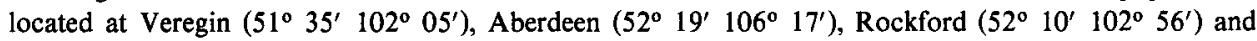
Hagen $\left(52^{\circ} 56^{\prime} 105^{\circ} 33^{\prime}\right)$. M. rotundata cells were taken from the Veregin population for comparative analyses (Tables 2 and 5 ).

\section{Storage}

Celles were placed in storage at $4^{\circ} \mathrm{C}$ on October 10,1979. Relative emergence times (Fig. 3) were evaluated by removing the cells from cold storage on April 25,1980 and incubating at $25^{\circ} \mathrm{C}$ or $30^{\circ} \mathrm{C}$. 
Field Placement of Native Cells

In an attempt to domesticate native leafcutter bees, 8200 native cells were placed at the bottom of tunnels in polystyrene hives and "Pollitec" circular hives. The cells were then incubated at $30^{\circ} \mathrm{C}$ for 12 days and placed in a five acre alfalfa field surrounded by native vegetation. Wooden hives of aspen and pine were also placed in the shelter. Tunnel diameters varied from 6.5 to $7.0 \mathrm{~mm}$ in both aspen and polystyrene hives to $6.0 \mathrm{~mm}$ in the pine hives.

$X$-ray Analyses

X-rays were taken on a Picker unit $(751-501,502)$ with a molybdenum X-ray tube. A 28 kilovolt setting was used to provide a 100 milliampere current for a 0.3 second duration. The tube was set at small focus approximately 26 inches from the leafcutter cells being exposed. The X-ray film was DuPont Nuclear Medicine Base F 31 vacuum pack, emulsion one side.

\section{RESULTS}

\section{Analysis of Leafcutter Cell Contents}

Virtually all of the immigrant native leafcutter bees observed were $M$. relativa, the only exceptions being two female $M$. nivalis. The proportion of females varied from $37 \%$ in the Veregin population to $63.8 \%$ in the Hagen population (Table 1). The

TABL. 1. - Leafcutter and parasite composition of four populations (expressed as percent of emerged cells).

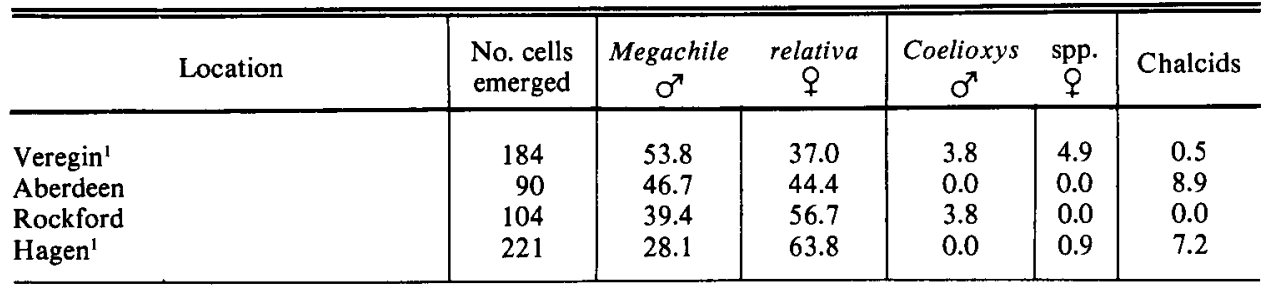

'Samples from each of these locations included $1 M$. nivalis 9 .

parasite populations were also variable since Veregin and Rockford native bee cells were infested with Coelioxys spp. whereas those from Aberdeen and Hagen populations were parasitized mainly by chalcids. A detailed comparison of the composition of cells sampled from the Veregin population is presented in Table 2. The most striking differences between native and domestic cells were the higher frequency of unemerged pupae in $M$. relativa and the absence of parasitism by Coelioxys spp. in $M$. rotundata. The viability of cells of $M$. rotundata $(84.0 \%)$ was higher than that of the native leafcutter cells $(69.6 \%)$. 
TABL. 2. - Comparison of contents of Megachile rotundata and M. relativa cells from Veregin population (expressed as percent of whole).

\begin{tabular}{l|c|c}
\hline \multicolumn{1}{c|}{ Cell Contents } & $\begin{array}{c}\text { M. rotundata } \\
\text { (264 cells in sample) }\end{array}$ & $\begin{array}{c}\text { M. relativa } \\
(248 \text { cells in sample })\end{array}$ \\
\hline Megachile & 84.0 & 69.6 \\
Coelioxys spp. & 0.0 & 6.3 \\
Chalcids & 0.0 & 0.4 \\
Unemerged larvae & 7.2 & 10.6 \\
Unemerged pupae & 0.8 & 8.3 \\
Pollen, egg imprint & 4.0 & 1.6 \\
Pollen, no egg imprint & 2.4 & 2.0 \\
Empty & 1.6 & 1.2 \\
\hline
\end{tabular}

${ }^{1}$ Cell constructed but not filled with pollen.

\section{Species Distribution of Parasites}

Cells containing chalcids were identified prior to incubation by X-ray analysis. Typical X-rays of cells containing Dibrachys maculipennis, Melittobia chalybii and Pteromalus venustus are shown in Fig. 2. The large Veregin sample included all three chalcid species whereas the Hagen sample contained D. maculipennis and $P$. venustus and cells from Aberdeen were infested with $P$. venustus only (Table 3 ).

TABL. 3. - Proportion of chalcid species present in four Megachile relativa populations.

\begin{tabular}{|c|c|c|c|}
\hline Location & $\begin{array}{l}\text { Sample } \\
\text { size }\end{array}$ & Species identified & No. \\
\hline $\begin{array}{l}\text { Veregin } \\
\text { Aberdeen } \\
\text { Rockford } \\
\text { Hagen }\end{array}$ & $\begin{array}{r}8.200 \\
\\
90 \\
104 \\
221\end{array}$ & $\begin{array}{l}\text { Dibrachys maculipennis } \\
\text { Melittobia chalybii } \\
\text { Pteromalus venustus } \\
\text { Pteromalidae (undeveloped) } \\
\text { Pteromalus venustus } \\
\text { - } \\
\text { Dibrachys maculipennis } \\
\text { Pteromalus venustus }\end{array}$ & $\begin{array}{r}28 \\
1 \\
2 \\
2 \\
8 \\
- \\
4 \\
11\end{array}$ \\
\hline
\end{tabular}

Coelioxys spp. were identified prior to emergence on the ninth day of incubation. Female Coelioxys spp. were easily distinguished from $M$. relativa by their pointed abdomen (Fig. $2 \mathrm{E}$ ) while male Coelioxys spp. were identified by their slender abdomen (Fig. 2 F). C. funeraria, the predominant Veregin species, was approximately 10 times more abundant than C. moesta (Table 4). Both species had similar sex ratios. The Rockford sample contained the same species with C. funeraria the more frequent. 


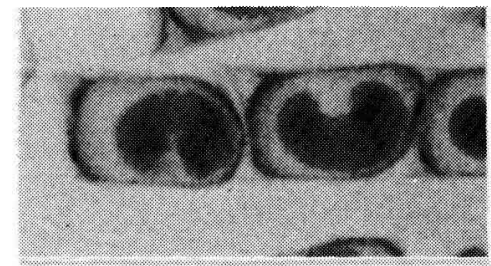

A

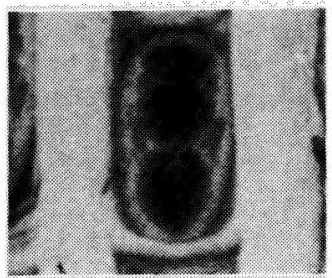

C

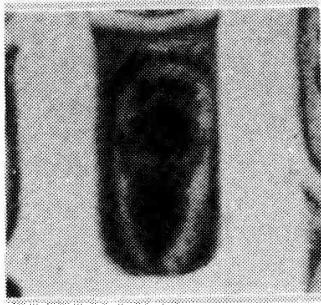

$E$

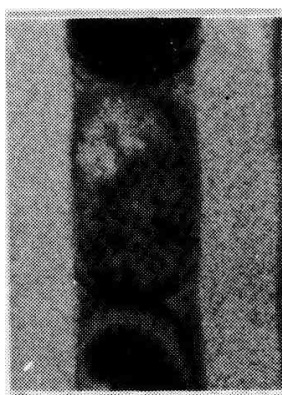

G

$H$

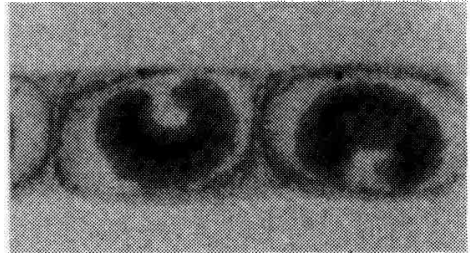

B

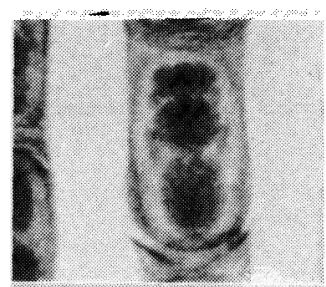

D

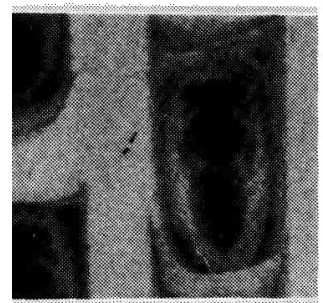

$\mathbf{F}$

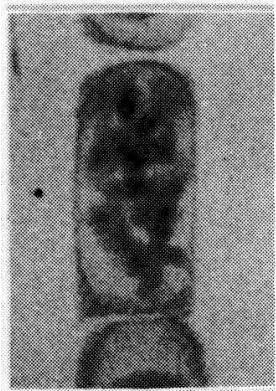

I

FIG. 2. - Photographs of $X$-rays of intact cells, distinguishing:
A) Megachile rotundata prepupae
C) M. relativa pupa Q
E) Coelioxys sp. pupa $ᄋ$
G) Melittobia chalybii
B) Megachile relativa prepupae
D) M. relativa pupa ó
F) Coelioxys sp. pupa $\sigma^{\prime}$
H) Dibrachys maculipennis

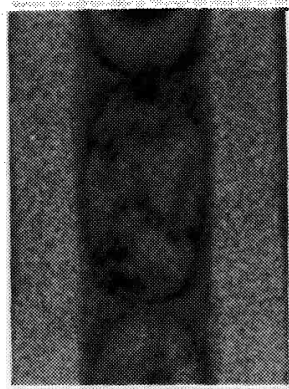

$1 \mathrm{~cm}$

I) Pteromalus venustus 
TABL. 4. - Proportion of Coelioxys species present in four Megachile relativa populations.

\begin{tabular}{l|c|c|c}
\hline \hline Location & $\begin{array}{c}\text { Sample } \\
\text { size }\end{array}$ & Species identified & No. \\
\hline Veregin & 8.200 & Coelioxys funeraria & $116 \sigma^{\prime}$ \\
& & Coelioxys moesta & 147 \% \\
& & & $12 \sigma^{\prime}$ \\
Aberdeen & 90 & Coelioxys funeraria & $-3 \sigma^{\circ}$ \\
Rockford & 104 & Coelioxys moesta & $10^{\circ}$ \\
Hagen & 221 & Coelioxys sp. & $1 q$ \\
\hline \hline
\end{tabular}

\section{Emergence}

Mean emergence times of $M$. relativa at $25^{\circ} \mathrm{C}$ and $30^{\circ} \mathrm{C}$ were 21 and 14 days, respectively (Fig. 3). Emergence of chaicids from native leafcutter cells incubated at

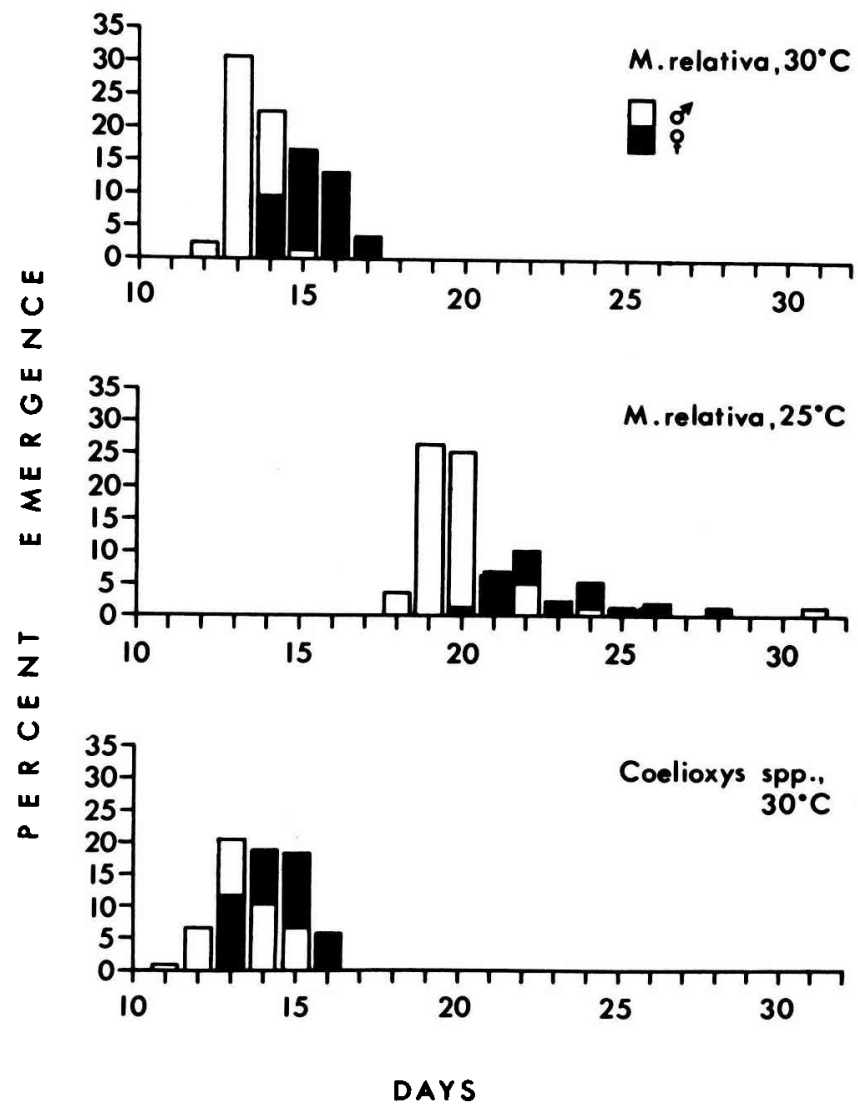

Fig. 3. - Emergence of $\mathrm{M}$. relativa and Coelioxys spp. 
$30^{\circ} \mathrm{C}$ peaked at day 9 and was complete by day 14 . Chalcid emergence from $M$. rotundata cells was similar (HoBBs, 1968). Emergence of Coelioxys spp. coincided with that of $M$. relativa (Fig. 3).

\section{Comparison of Native and Domestic Leafcutter Cells}

As seen in Fig. 1, cells of $M$. relativa are distinguishable by their large size and smooth texture. Weight differences are given in Table 5. M. relativa cells contained approximately $20 \%$ more pollen than those of $M$. rotundata. Both species showed a preference for the leaves of Rosa and Prunus species in construction of cells.

\section{Field Observations of M. relativa}

Although $8,200 \mathrm{M}$. relativa cells were placed in hives, only 1,280 cells were harvested from these hives at the end of the field season. Assuming a production of eight cells per female (MEdLer and KOERBER, 1958), the resident female population would theoretically have been about 160 . This represents $4.8 \%$ of the original population's female component if we consider the male : female ratio to have been approximately $1.5: 1$ (Table 1 , Veregin population). Our field observations during emergence in early summer indicated that few females remained in the vicinity of the hives, whereas male $M$. relativa were seen in abundance hovering over hives and inspecting tunnels. Occasionally empty cells of $\dot{M}$. relativa were used by $M$. rotundata (Fig. 1), the latter having drifted from commercial shelters in the same field. $M$. relativa females were not observed to be aggressive to each other, choosing tunnels relatively close (often adjacent) to each other. The majority of the occupied tunnels were in a small area of one polystyrene hive. M. relativa was observed to collect alfalfa pollen but had a strong preference for that of Sonchus arvensis (sow thistle).

TABL. 5. - Cell, prepupal and pollen weights (mg. \pm S.E.) for M. rotundata and $\mathrm{M}$. relativa from Veregin population.

\begin{tabular}{l|c|c|c}
\hline \hline & Cell & Prepupa & Pollen (dry wt.) \\
\hline$M$. rotundata & $37 \pm 2.9$ & $52 \pm 3.4$ & $81 \pm 5.0$ \\
$M$. relativa & $65 \pm 4.7$ & $63 \pm 3.3$ & $107 \pm 7.8$ \\
\hline \hline
\end{tabular}

\section{DISCUSSION}

In view of earlier reports on the many different species of leafcutter bees found active on alfalfa (Sladen, 1918; PeCK and Bolton, 1946; HobBs and Lilly, 1954; STEPHEN, 1955) it was of interest that the main leafcutter we found in commercial nests 
was $M$. relativa. Only two $M$. nivalis females appeared in the identification of 599 adults (Table 1) indicating that this species infiltrated commercial populations to a lesser extent in areas from which samples were taken. Ground nesting species ( $M$. dentitarsus, $M$. perihirta, $M$. diligens, $M$. latimanus) would not be expected to nest in commercial hives. However, the absence of M. gemula, M.frigida, $M$. melanophaea, $M$. inermis and of appreciable numbers of $M$. nivalis is not easily explained. PECK and BolTON (1946) found that artificial nests bored in logs and stumps resulted in the capture of $M$. frigida and $M$. nivalis. The large size of $M$. inermis and $M$. frigida likely prevents their acceptance of commercial tunnels $(6.0$ to $7.0 \mathrm{~mm}$ diameter) but these tunnel sizes should not restrict $M$. nivalis, $M$. gemula, or $M$. melanophaea more than $M$. relativa.

A comparison of $M$. rotundata and $M$. relativa cells in the Veregin population (Table 2) shows that there is a much higher pupal mortality in $M$. relativa, the basis of which is unknown. The absence of Coelioxys parasitism in M. rotundata has been verified by analyses of many populations (authors, unpublished data). Although there are reports of parasitism by Coelioxys spp. in native Canadian leafcutters (FYE, 1965; PeCK and Bolton, 1946), the only reports of Coelioxys parasitism in M. rotundata are in European populations. AsENsio and Rodriguez (1972), in Spain, and MANNINGER (1972), in Hungary, report $C$. rufocaudata as an important parasite. TASEI $(1975,1977,1979)$ reported that in France, Coelioxys has become the major parasite in some $M$. rotundata populations. C. rufocaudata may be adapted to $M$. rotundata in Europe because the latter is native to southern Europe. However, in Canada, C. funeraria and $C$. moesta have adapted to larger native species such as M. relativa. The larger prepupa of native Coelioxys spp. may not be able to develop on the provisions of a $M$. rotundata cell. This interpretation is supported by the observation that $20 \%$ more pollen is stored by $M$. relativa (Table 5). Control of Coelioxys spp. is difficult in $M$. relativa because of similar emergence times (Fig. 3 ), however, X-ray analysis of pupae could be used to identify Coelioxys in time for removal.

Three species of chalcids, D. maculipennis, $M$. chalybii and $P$. venustus, were observed in $M$. relativa cells (Table 3). This is in agreement with reports on $M$. relativa in Wisconsin, where $M$. chalybii and Dibrachys sp. were observed (MEDler and Koerber, 1958), and in northwestern Ontario, where $M$. chalybii was observed in a few $M$. relativa cells (FYE, 1965).

Chalcid species reported to parasitize $M$. rotundata in Canada are Monodontomerus obscurus, P. venustus and M. chalybii (Новвs, 1968; PeCK, 1969; Hobss and KRUNIC, 1971). This suggests that M. obscurus may be specific to $M$. rotundata, and that D. maculipennis is a successful parasite only on native species. Further investigation is required to substantiate this possibility, in view of the varied chalcid composition in the four populations studied (Table 3 ). 
Domestication of $M$.relativa is an interesting possibility since it has been observed to fly at lower temperatures than M.rotundata. The solitary nature of M. relativa and related species (HoLM and SKou, 1972) was verified by our low recovery of cells under domestic conditions. However, the 1280 cells recovered may represent the progeny of selected $M$. relativa females with a gregarious habit. This possibility will be evaluated by further field studies.

\title{
ACKNOWLEDGEMENTS
}

We gratefully acknowledge M. IvanochKo, Biosystematic Research Institute, Ottawa, for the identification of Megachile, Coelioxys and chalcid species, and the Department of Radiology, University Hospital, Saskatoon, for X-ray exposures.

Received for publication in January 1981.

\author{
RÉSUMÉ \\ LES ESPÈCES DE MÉGACHILES INDIGĖNES ET LEURS PARASITES \\ DANS LES NICHOIRS COMMERCIAUX DU SASKATCHEWAN
}

On a récolté des cellules de mégachiles indigènes dans 4 populations utilisées commercialement au Saskatchewan et identifié les adultes sortis de 599 cellules provenant de ces populations. 597 d'entre eux étaient des Megachile relativa et 2 des $M$. nivalis.

La comparaison du parasitisme dans les cellules de $M$. relativa et $M$. rotundata montre que seules les cellules de $M$. relativa sont parasitées par Coelioxys funeraria et $C$. moesta. On a identifié 3 espèces de chalcidés dans les cellules de $M$. relativa : Dibrachys maculipennis, Melittobia chalybii et Pteromalus venustus. Puisque $M$. rotundata est connu pour être parasité par Monodonterus obscurus, $P$. venustus et $M$. chalybii, il est possible que $M$. obscurus soit spécifique de $M$. rotundata, alors que $D$. maculipennis ne se développe que sur les espèces indigènes.

La durée moyenne de développement de $M$. relativa à $25^{\circ} \mathrm{C}$ et $30^{\circ} \mathrm{C}$ est respectivement de 21 et 14 jours. Les chalcidés éclosent du $9^{e}$ au $14^{e}$ jour lorsque l'incubation des cellules a lieu à $30^{\circ} \mathrm{C}$, tandis que l'éclosion de Coelioxys spp. coïncide avec celle de $M$. relativa.

L'analyse aux rayons X permet d'identifier les nymphes mâles et femelles de $M$. relativa et Coelioxys spp. le $9^{\mathrm{e}}$ jour de l'incubation. Ce procédé permet de supprimer Coelioxys spp. avant de lâcher en champ $M$. relativa. On a introduit 8200 cellules de $M$. relativa (indemnes de Coelioxys spp.) dans des nichoirs que l'on a placés à l'extérieur. Seules 1280 cellules filles ont été récoltées car les insectes ont déserté l'abri.

\section{ZUSAMMENFASSUNG}

\author{
EINHEIMISCHE ARTEN DER BLATTSCHNEIDEBIENE UND IHRE PARASITEN \\ IN DEN KOMMERZIELLEN NISTSTÄTTEN IN SASK ATCHEWAN, CANADA
}

Zellen von einheimischen Blattschneiderbienen wurden aus vier kommerziellen Populationen in Saskatchewan gesammelt. Die geschlüpften adulten Tiere aus insgesamt 599 Zellen aus diesen vier Populationen wurden bestimmt. Von diesen wurden 597 als Megachile relativa und zwei als M. nivalis identifiziert. 
Ein Vergleich der Parasitierung bei Megachile relativa und $M$. rotundata ergab, dass nur die Zellen von $M$. relativa von Coelioxys funeraria und $C$. moesta parasitiert waren. Die drei Chalcididen-Arten, die in $M$. relativa-Zellen bestimmt wurden, waren folgende : Dibrachys maculipennis, Melittobia chalybii und Pteromalus venustus. Da für $M$. rotundata die Parasitierung durch Monodontomerus obscururs, $P$. venustus und $M$. chalybii gemeldet worden ist, stellen wir die Möglichkeit zur Diskussion, dass $M$. obscurus für $M$. rotundata spezifisch sei, während $D$. maculipennis nur bei einheimischen Arten erfolgreich ist.

Die mittlere Zeitspanne bis zum Schlüpfen betrug für $M$. relativa bei $25^{\circ} \mathrm{C}$ und bei $30^{\circ} \mathrm{C} 21$ Tage, bzw. 14 Tage. Die Chalcididen schlüpften von Tag 9 bis Tag 14, wenn die Zellen bei $30^{\circ} \mathrm{C}$ erbrütet wurden; der Schlüpftermin von Coelioxys spp. hingegen fiel mit dem von $M$. relativa zusammen.

Durch Röntgen-Analyse gelang es, am 9. Bruttag männliche und weibliche Puppen von $M$. relativa und Coelioxys spp. zu bestimmen. Mit dieser Methode wurde es möglich. Coelioxys spp. vor der Aussetzung im Feld von den $M$. relativa-Puppen auszusondern. $8.200 \mathrm{M}$. relativa-Zellen (frei von Coelioxys spp.) wurden in Kästen gesetzt und unter Freilandbedingungen aufgestellt. Als Folge des Verfluges von diesem Freiland-Nistplatz wurden nur 1.280 Nachkommen-Zellen gewonnen.

\section{REFERENCES}

Asensio de la Sierra E., Rodriguez Ibanez J. A., 1972. - Primer informe sobre adaptacion y multiplicacion de la abeja polinizadora de la alfalfa Megachile pacifica Panz. (Megachile rotundata auct. nec. Fabr.). An. Inst. Nac. Invest. Agrar. Ser. Prot. veg., 2, 237-252.

FYE R. E., 1965. - Biology of Apoidea taken in trap-nests in northwestern Ontario (Hymenoptera). Can. Ent., 97, 863-877.

Gentry G. T., 1874, - Notes on Megachile centuncularis. Can. Ent., 6, 171-175.

Hоввs G. A., 1968. - Controlling insect enemies of the alfalfa leafcutter bee, Megachile rotundata. Can. Ent., 100, 781-784.

Hobbs G. A., KRUNiC M. D., 1971. - Comparative biology of three chalcidoid (Hymenoptera) parasites of the alfalfa leafcutter bee, Megachile rotundata, in the laboratory. Can. Ent., 103, 674-685.

Новвs G. A., Lilly C. E., 1954. - Ecology of species of Megachile Latreille in the mixed prairie region of southern Alberta with special reference to pollination of alfalfa. Ecology, 35, 453-462.

Holm S. N., SKou J. P., 1972. - Studies on trapping, nesting and rearing of some Megachile species (Hym. Megachilidae) and on their parasites in Denmark. Entomologica Scandinavica, 3, 169-180.

KrombeIN K. V., 1967. - Trap-nesting wasps and bees : life histories, nests, and associates. Smithsonian Press, Washington, D.C.

MANNINGer S., 1972. - Parasites of alfalfa leafcutter bee, Megachile rotundata F. (M. pacifica Panz.) in Hungary. Novenytermeles, 21, 321-328.

Medler J. T., Koerber T. W., 1958. - Biology of Megachile relativa Cresson (Hymenoptera, Megachilidae) in trap-nests in Wisconsin. Ann. Ent. Soc. Amer., 51, 337-344.

PECK O., 1969. - Chalcidoid (Hymenoptera) parasites of the alfalfa leafcutter bee, Megachile rotundata, In Canada. Can. Ent., 101, 418-422.

Peck O., Bolton J. L., 1946. - Alfalfa seed production in northern Saskatchewan as affected by bees, with a report on means of increasing the populations of native bees. Sci. Agric. 26, 338-418.

SLAden F. W. L., 1918. - Pollination of alfalfa by bees of the genus Megachile. Table of Canadian species of the latimanus group. Can. Ent., 50, 301-304.

STEPheN W. P., 1955. - Alfalfa pollination in Manitoba. J. Econ. Entomol., 48, 543-548.

TASEI J.-N., 1975. - Le problème de l'adaptation de Megachile (Eutricharea) pacifica Panz. (Megachilidae) Américain en France. Apidologie, 6, 1-57.

TASEI J.-N., 1977. - Possibilité de multiplication du pollinisateur de la luzerne Megachile pacifica Panz. en France. Apidologie, 8, 61-82.

TASEI J.-N., 1979. - Pollinisation de la luzerne par les megachiles. Expérimentation 1979. Laboratoire d'Éthologie et d'Écologie des Insectes, I.N.R.A., Lusignan. 